\title{
Teaching Persian Subjunctive Mood to Non- Persian Students Based on Cognitive Linguistics (Mental Spaces Theory)
}

\author{
Ferdows Aghagolzadeh Silakhori \\ Tarbiat Modares University, Tehran, Iran \\ Email: aghagolz@modares.ac.ir \\ Zahra Abbasi \\ Tarbiat Modarres University, Tehran, Iran \\ Email: z_h_abbasi@yahoo.com
}

\begin{abstract}
It's a long time that teaching Persian to foreigners has established its status as a technical major among other academic fields and in this regard various educational sources have been compiled and developed and Persian teachers apply new principles and methods of foreign language teaching in their classrooms. Meanwhile, findings of linguistics have undoubtedly had a significant influence on the development of teaching methods. One of the new linguistic approaches is cognitive approach. This article tries to examine the use of one of linguistic theories, i.e. mental spaces, in teaching Persian subjunctive mood. Foreign students of Shahed University were chosen in order to explore the effect of this concept on the learning and correct application of subjunctive mood. These students, in two groups of engineering and medicine, were studying Persian as their general course at Shahed University. The results of the study revealed that the use of mental spaces concept is effective and efficient for teaching subjunctive mood.
\end{abstract}

Index Terms - cognitive linguistics, second/foreign language instruction, Persian language teaching, subjunctive mood

\section{INTRODUCTION}

Unfortunately, no research has been conducted on teaching Persian to non-native speakers using cognitive linguistic theories. With a short glance at the existing sources and methods of teaching Persian language, this article tries to introduce and investigate the application of cognitive linguistics in teaching subjunctive mood. Teaching subjunctive mood was chosen because writing and speaking skills of Persian learners, even those in advanced levels of language proficiency, show that they have difficulty in the comprehension and correct use of this mood.

\section{REVIEW OF LITERATURE}

\section{A. Cognitive Linguistics and Second/Foreign Language Teaching}

So far, extensive researches have been conducted regarding the effect of cognitive linguistics on second/foreign language teaching, and various books and articles have been published in this way, including Achard and Niemeier (2004), Dirven and Verspoor (2004), Putz, Niemeier and Dirven (2001). Moreover, regarding cognitive approach to second language teaching, Ellis and Robinson (2008, p. 4-8) contend that based on cognitive linguistics, language is learned through usage.

Rod Ellis regards language teaching generally as a mental process and explains this subject in details (Ellis, 2008 a, p. 405). Many researches have also been conducted on the cognitive processes and strategies in learning and acquisition of second/foreign language (Oxford, 1990) Schmidt (1994), Tomlin \& Villa (1996), VanPatten (1996), Eysenck (2001), Gass (1997), Ellis \& Robinson (2008 b).

Stating that the difference in form is used for showing the difference in function, and that form and function are interrelated, Gass and Selinker (2008, p. 206) have raised this question that how do language learners realize to use appropriate morphological markers with related verb? Then, referring to researches conducted on learning morphological markers, tense and aspects of verbs, they have come to the conclusion that first and second language learners are influenced mostly by semantic aspect of verbs or propositions, and that focus on meaning and impact of semantic meaning are very important in second language acquisition.

\section{B. Modality and Subjunctive Mood}

Every verb possesses features including tense, person, mood, aspect and voice. Each of these features has specific formal and semantic markers which explain their nature and function (Shafaee, 1984). 
Mirza Habib Isfahani (1308 A.H, p. 62), Abdol Azim Khan Qarib (1955, p. 115-116), Yasemi et.al (1994, p.140), Khayampour (1996, p84), Homayoun Farrokh (1985, p.482), Natel Khanlari (1987, p.30), Ahmad Giwi (2001, vol. 2: p,19-12), Farshidvard (1969, p.120; and 2003, p. 381), Ali Ashraf Sadeghi and Gholam Reza Arzhang (1982, p. 6-7), Vahidian Kamyar and Omrani (2002, p. 54-55) all have studied mood, and categorized it into three to six types which consist of indicative, subjunctive, conditional, imperative, participial and infinitive. The three moods of indicative, subjunctive and imperative are shared by the above mentioned works. Subjunctive mood, therefore, is the common mood among these grammarians, for which they have mentioned the meaning of doubt and hesitation, probability, wish, desire, hope, prediction, assumption, command, recommendation and request.

Shafaee (1984, p. 88-91) as well regards subjunctive mood as speaker's or writer's interactions, expressed through verb in the form of obligation, wish, doubt and hesitation. He believes that speaker's interactions are the main factors in the determination of moods, and summarizes interactions of subjunctive mood in two major concepts of desire and hesitation. He also believes that the concept of desire mostly appears in subjunctive present, because wishes and desires of human beings are often in relation to the future. The concept of hesitation appears more in subjunctive past, since people often become hesitant and doubtful about actions and events which have been done and occurred in the past.

According to English grammar books (Chalker, 1995; Fowler, 1926; Hardie, 1990), subjunctive mood are used to express wish, conception, goals, doubt and assumptions, and conditional sentences. Regarding this, John Saeed (1997) states that subjunctive mood is defined differently in different languages, but it has mainly two dimensions of usage: the syntactic usage, which shows the boundness of the sentence, and in this case subjunctive mood is used with the verb in the bound clause, and the semantic usage, in which subjunctive mood shows the counterfactual mood and is used to express wishes, believes, commands and requests. This mood is the opposite of indicative mood which describes factual realities.

Mortelmans (2007, p. 868-890) has investigated modality in cognitive linguistics and contends that research on modality and moods has a long history, and that linguists, philosophers and logicians have worked on this subject. More than two thousand years ago, Aristotle referred to the rational relationship between probability and modality. In the second half of the $20^{\text {th }}$ century, with the spread of modern linguistics, modality attracted the attention of linguistic schools, and traditional grammar, semantics, generative grammar, pragmatics, semiology, systemic-functional grammar and cognitive grammar have all dealt with this subject (Mortelmans, 2007). According to Lyons (1977, p, 541), modality is concerned with people's attitude and their beliefs regarding stated propositions and also with the optional particles described by these propositions. Quirk (1985, p.219) considers modality as the speaker's judgment about validity and truth of propositions. Palmer (1986, p.16) believes that modality is the grammaticalization of mental attitudes and believes of the speaker, and Jian Li (1999, p.21) views modality as degrees between correct and incorrect. Systemic-functional grammar, introduced by Halliday (1985, 1994 and Halliday and Matthissen 2004), is based on function. Halliday has studied modality and subjunctive mood in details and rejects the idea that modality is often reflected by modal verbs (like what is expressed in traditional grammar). Introducing experimental, interpersonal, and textual metafunctions, he claims that mood and modality are important issues in interpersonal metafunction. Lamport and Lampart (2000, p.296) have also assumed modality as a theoretically important category and declared that modality assigns a single semantic label to a formal category of modal verbs. Form cognitive linguistics viewpoint, modal expressions include adjectives, adverbs, mental propositions, connotative markers and lexical verbs as well.

\section{Teaching Persian Subjunctive Mood to Foreigners}

In different sources of Persian teaching, subjunctive mood has been taught to foreigners within separate sentences which consist of modal verbs such as xăstan (want), tavănestan (can), dust dăštan (like), băyad (must), săyad (may be) etc. These sources have just merely discussed the formal differences between subjunctive mood and indicative mood, and the lexical meaning of modal verb used in the sentence. In these sources, imperative, compound and conditional sentences are taught separately and here too just the formal construction of protasis, apodosis, main clause and bound clause has been aimed at. In none of the sources, the attitude of the speaker of the sentence regarding the probability of occurrence of the verb, and effect of this attitude on mood choice is discussed. Moreover, since different kinds of compound sentences are taught separately and gradually, the meaningful relationship of mood choice in such sentences is ignored.

Persian teaching sources have dealt with the traditional teaching of moods, and have gradually taught subjunctive mood usage in simple and compound sentences. The relationship between such usages has been disregarded in all this sources.

In this article, major educational sources applied in different educational centers inside and outside Iran are examined. Since indicative mood has appeared gradually and in various units, and as the main topic of the article is devoted to teaching subjunctive mood, therefore, the subjunctive and imperative moods in sources are just dealt with. No article or research having specifically investigated this subject was found.

\section{Saffar Moghadam}

In General Persian (1) Main Structures (2003), Saffar Moghadam has presented subjunctive mood and present and past subjunctive in comparison to present indicative and with the use of modal verbs, and he has taught the use of this mood in compound and conditional sentences in later units. This method also appears exactly in four-volume series of 
Teaching Persian Language (2007). In both works, imperative verb is assumed to be constructed form the combination of prefix "be" and present stem.

\section{Zarghamian}

In the book titled Fast-to-Learn Persian language (2002) and three-volume series of Persian Language Teaching (2003), Zarghamian has taught constructing imperative mood by comparing present verb, (for example, to mixori (you sing. eat, indicative) $\rightarrow$ boxor (Eat!, imperative), shoma mixorid (you plu. eat, indicative) $\rightarrow$ boxorid (Eat!)) and in General Series of Persian Language, Basic Level, he has taught construction of the imperative verb through subjunctive mood (for example, băyad boxori (you sing. should eat) $\rightarrow$ boxor (Eat!), băyad boxorid (you plu. should eat) $\rightarrow$ boxorid (Eat!)).

In Fast-to-Learn Persian language, subjunctive mood, like all the other structures, is taught through dialogues and short questions and answers, and its morphological analysis is not discussed. In the three-volume series this trend is followed as well, and the morphological analysis of subjunctive present is also presented.

In General Series of Persian Language, Basic Level (2010), in addition to above-mentioned points, it is shown that subjunctive mood is used to express possibility, or probability, or desire for doing something.

\section{Pournamdarian}

Pournamdarian (2007) has taught present subjunctive in unit six and unit eight, section three as well, past subjunctive in unit nine, section three, conditional sentences in unit ten, section three and imperative verb in unit twenty, section two. Concerning imperative verb, present and past subjunctive, he works on verb analysis. Pournamdarian believes imperative verb is the result of combining prefix "be" and present stem. He repeats this point exactly for present subjunctive, and views it as the outcome of the combination of prefix "be" and present stem, without referring to the differences and similarities between these two. He also considers past subjunctive as the combination of past participle and present subjunctive of the verb "budan (to be)". Providing no explanation about meaning or usage of mentioned moods, he introduces decontextualized examples in the form of separate sentences; at the end, some exercises have been given. This pattern is followed for teaching all grammatical structures.

\section{Samareh}

In his five-volume book, titled "AZFA", to teach subjunctive present and past, Samareh (1993), like Pournamdarian depends on morphological analysis and considers constructing subjunctive present as the combination of prefix "be" + present stem + personal ending, and he regards subjunctive past as past participle of the main verb+ the subjunctive present of "budan (be)" verb, and he views imperative mood as "be" + present stem. In "AZFA" too, examples and exercises, followed by some practices are presented in individual and decontextualized sentences.

\section{Ebrahimi}

Ebrahimi (2009), in his "advanced writing (for non-Iranian language learners)," teaches various types of compound sentences, explaining how to combine two simple sentences with different conjunctions to construct new compound sentence, and he also describes the way to represent verb mood in various compound sentences. The point which was ignored by Ebrahimi and others is that this representation of moods in different sentences is regular. Through the gradual and separate presentation of compound sentences this regularity is disregarded.

\section{THEORETICAL FOUNDATIONS}

\section{A. Mental Spaces}

One of the main theories proposed by cognitive linguists, especially Fauconnier $(1985 ; 1994)$; Fauconnier \& Sweetser (1996); Fauconnier \& Turner (2002) is mental spaces theory. This theory is in fact parallel to possible worlds, which had been introduced by Leibnitz before. Recognition occurs through mental spaces in comparison to existing spaces in the real world, and a significant part of our cognition seems to materialize through comparison between mental spaces.

Mental spaces are very partial assemblies constructed as we think and talk, for purposes of local understanding and action. They contain in elements and are structured by frames and cognitive models. Mental spaces are constructed and modified as thought and discourse unfolds and are connected to each other by various kinds of mappings, in particular identity and analogy mappings. It has been hypothesized that at the neural level, mental spaces are sets of activated neuronal assemblies and that the connections between elements correspond to coactivation-bindings .

Under the mental space view, language comprehension and production involves the construction of hierarchically organized and interconnected cognitive domains, domains which are independent of language but which language depends on for the interpretation of meaning. Language is the superficial manifestation of these underlying, highly abstract cognitive constructions. Sentences give partial and underdetermined instructions for: the construction of domains; the subdivision or partitioning of information into different domains; the internal structuring of elements and relations within each domain; and the construction of connections between elements in different domains and connections between the domains themselves. These domains are referred to as mental spaces (Fauconnier 1985).

Mental spaces correspond to "understandings" of a sentence within a context (Ibid). Mental spaces are very partial structures which may represent pictures, beliefs, hopes, stories, propositional attitudes, hypothetical realities, thematically or topically defined domains, quantified domains, situations located in time or space, etc... 
Each space is a partial representation of "some logically coherent situation or potential reality, in which various propositions are treated as true, objects are assumed to exist, and relations between objects are supposed to hold" (Dinsmore 1991:49).

As discourse is processed, new mental spaces may be built as a result of cues provided by space-builders, by grammatical markers such as tense and mood, or by pragmatic information. 'Space-builders' may take a variety of grammatical forms: prepositional phrases, connectives, complement taking clauses, etc... (for example: in the picture, in 1989, at school, from her point of view, if __, Roger said __, John believes __, Mary hopes __). In the absence of more explicit space-builders, tense and mood may cue construction of spaces. Spaces may also be built on the basis of implicit pragmatic cues. For example, a speech situation may implicitly set up a space for what is to be communicated between speaker and hearer. A space for the speaker's conception of reality, space R, is always constructed by default. Note that a space-building expression may also serve simply to relocate a space already constructed from the preceding discourse, in which case no new space is constructed (Cutrer, 1994 p.49-50). Fauconnier (1985, p.130) believes that one kind of space-builders is modal verbs.

According to mental spaces theory, three mental spaces can be thought of for choosing mood: the first is the one in which, from speaker's viewpoint, verb occurrence is inevitable, the second one is the one in which verb occurrence is not inevitable and speaker doesn't assure the listener about occurrence of the verb, and in the third mental space the speaker is sure that the verb occurrence is impossible and improbable. These three spaces can be called indicative/ inevitable spaces, subjunctive/possible spaces, and counterfactual/ impossible spaces respectively. In indicative space, indicative mood (different future tenses, indicative present, present continuous and different kinds of past (simple, continuous, perfect, present perfect) is used. In subjunctive space, subjunctive present and past tenses, and in improbable space, past continuous and past perfect are used. Therefore, "probability of occurrence" can be considered as the shared meaning of moods, and according to this shared meaning different mental spaces can be built.

\section{B. A New Look at the Subjunctive Mood in Persian Language}

By investigating Persian grammar sources, and construction and use of subjunctive mood, it can be stated that the use of subjunctive mood in Persian language is in fact speaker-based, and the speaker uses subjunctive mood when he thinks the probability of verb occurrence is not inevitable. This lack of inevitability in verb occurrence is shown by modal verbs and adverbs such as xăstan (want), tavănestan (can), dust dăštan (like), băyad (should), šăyad (maybe) etc..., but these markers don't exist in all sentences. The formal marker of the subjunctive mood in present subjunctive tense is the verbal prefix of "be", and for present indicative the prefix "mi" is used.

- Ali be širăz mi(indicative prefix) ravad.

Ali to Shiraz go (present indicative).

- Ali šăyad be širăz be(subjunctive prefix) ravad. Ali maybe to Shiraz go (present subjunctive).

Subjunctive past tense is made of past participle of the verb plus present subjunctive of "budan (to be)" verb and indicates that speaker, before uttering the sentence, is doubtful about verb occurrence.

- Ali be širăz rafte ast. (Ali has gone to Shiraz) Ali to Shiraz gone is (indicative).

- Ali šăyad be širăz rafte bashad. (Ali may have gone to Shiraz)

Ali maybe to Shiraz gone is (subjunctive).

The speaker's lack of inevitability about verb occurrence in present and future tense is expressed by subjunctive present tense, and before uttering the sentence is expressed by subjunctive past. In short, the usage of present and past subjunctive can be classified as the following (it should be noted that in all the examples in which subjunctive mode is used, the speaker has constructed the sentence in the subjunctive mental space and is not sure about verb occurrence):

\section{Subjunctive present tense:}

The subjunctive present tense is used:

1. To express something as a recommendation or advice:

- Behtar ast be pezešk morăje'e bekonid (present subjunctive tense).

better is to a doctor refer. (You'd better see a doctor)

In this sentence the phrase "behtar ast" acts as the space-builder and forms a subjunctive space in which occurrence of the verb "morăje'e konid" is not inevitable. If occurrence of the verb was inevitable, this sentence would be used:“ šomă be pezešk morăje'e mikonid (you see a doctor)".

2. To make a suggestion:

- Miăy berim sinema?

come (you) go (we) (present subjunctive) cinema? (Shall we go to cinema?)

3. Subjunctive present verb in the form of third person singular and plural in independent sentence indicates command or prohibition. In this kind of imperative sentence, the speaker assumes the high improbability of the listener not to obey his command and from speaker's opinion verb occurrence is not inevitable/ definite.

- Ali fardă be madrese naravad.

Ali tomorrow to school doesn't go (present subjunctive). (Ali, doesn't go to school tomorrow) 
4. To express wish, hope or curse:

- Xodă šomă ră hefz konad.

God you (accusative marker) protect (present subjunctive). (May God protect you.)

- Kăš biăyad!

wish come (s/he) (present subjunctive). (I wish s/he would come.)

5. To accept a suggestion, to make concession and to accept the opposite of something which was expected:

- -Berim sinemă?

go (we) (present subjunctive) cinema. (Shall we go to cinema?)

- -Băše berim, man movăfeqam.

ok go (we) (present subjunctive). I agree am. (Ok, let's go, I agree.)

6. To express anger or refusal:

- Man begorizam!

I run (I) (present subjunctive). (I'm running away!)

7. To express hesitation, being in limbo or anxiety:

- Če konam?

what do (I) (present subjunctive)? (What should I do?)

8. In bound clause of compound sentences:

- Lăzem bud ke u be injă biăyad. (obligation)

necessary was that s/he to here come (present subjunctive). (It was necessary for him/her to come here.)

- Băvar nemikonam ke u beravad.

don't believe (I) that s/he go (present subjunctive). (I can't believe that he leaves here.)

- U mitarsad ke in kăr ra anjăm dahad.

he afraid that this work do(present subjunctive). (He is afraid of doing this.)

- Ănhă haq nadărand in kăr ra bedoune ejăzeye ma anjăm dahand.

They aren't allow this work without permission our do(present subjunctive). (They aren't allowed to do this without our permission.)

- Ǎrezu-ye man in ast ke xošbaxt šavi.

wish my this is that prosperous become (you) (present subjunctive). (I wish that you would be prosperous.)

- Ǎnče ra bekărid, dero xăhid kard.

what plant (you) (present subjunctive), will reap (you) (present indicative). (you would reap what you plant.)

- Injă bemănid, tă man bargardam.

here stay (you) (present subjunctive), until I come back (present subjunctive). (Stay here till I come back.)

- Piš az ănke u beresad, az injă miravam.

before he arrive (present subjunctive), from here go (I) (present indicative). (I'll leave here before he arrives.)

- Kăr kon, ta movafaq šavi.

work (you) (imperative), so succeed (you) (present subjunctive). (Try, so that you succeed.)

- Hasan dar xăne mănd, ta kăraš ra tamăm konad.

Hasan in home stayed (present indicative), until work his finish (present subjunctive). (Hasan stayed at home to finish his work.)

9. In probable conditional sentences the verb of conditional clause (protasis) is in most cases in the subjunctive present:

- Agar dar qor'ekeši barande shavi, če mikoni?

if in lottery win (you) (present subjunctive),what do (you) (present indicative)? (What will you do if you win a lottery?)

\section{Subjunctive past tense}

1. Past subjunctive is used in the conditional clause of conditional sentences:

- Agar u mariz šode băshad, to hič komaki nemitavăni be u bekoni.

if he sick is(past subjunctive), you nothing help cannot to him do(present subjunctive). (if he is sick, you can do nothing for him.)

2. In bound sentences

- Momken ast diruz Ali ănhă ră dide băšad.

possible is yesterday Ali them see (past subjunctive). (Ali may have seen them yesterday.)

- Mădar tavaqo' dăšt ke Năder be Esfahăn reside băšad.

Mother expected that Nader to Esfahan arrived (past subjunctive). (Mother expected that Nader had arrived Esfahan.)

- Ănhă ehtemăl midahand ke bače-hă sorxak gerefte băšand.

They probability give that children measles inflicted (past subjunctive). (They think it's probable that the children have been inflicted with measles.)

- Fekr mikonid ke u hălă digar reside bǎšad?

think (you) that he by now arrive (past subjunctive)? (Do you think he has arrived by now?) 
As it is seen in the examples, in all the sentences, modal verbs, which are a sign of using subjunctive mood of the main verb, aren't used. It is in such sentences that most language learners have problem in choosing mood. Subjunctive mood in different compound and simple sentences can be justified by the use of mental space concept. In general, Persian speaker assumes three mental spaces: indicative/inevitable, subjunctive/possible, and counterfactual/impossible mental space. In indicative mental space, the speaker believes that the verb of the sentence will occur and therefore he uses indicative mood. In the second mental space, the subjunctive space, the speaker believes that occurrence of the verb is not certain, thus applies subjunctive mood. In this space, there may be space-builders like modal verbs, the existence of which in the sentence helps the learner to correctly use the verb of the sentence in subjunctive form; But, as the examples show, not in all cases modal verbs are used in the sentences. The third mental space called counterfactual space, is the one in which the speaker is sure that the verb won't occur, so he applies two tenses of past continuous and past perfect such as

- Ey kăš fardă bă mă be širăz miămadi.

wish tomorrow with us to shiraz went (you past continuous). (I wish you would come to shiraz with us tomorrow.)

- Ey kăš diruz bă mă be shiraz amade budi.

wish yesterday with us to shiraz went (you past perfect). (I wish you would have come to shiraz with us yesterday.)

\section{The Experience of Teaching Subjunctive Mood to Persian Learners}

As the researcher's experience of several years of teaching, and also research on learning subjunctive mood in foreign students in Iran show, learning this mood is too difficult for language learners. Most Persian learners have problem in choosing suitable mood for the sentence, particularly when there is no specific makers, like modal verbs as the maker of mood and grammatical tense, in the sentence.

For example, in completing a sentence like

"Ănhă băyad fardă dar emtahăn . . . (šerkat kardan)"

They should tomorrow in exam...... .(take part) (They should... in the exam tomorrow. (to take part))

language learners make use of the modal verb "băyad (should)" as a marker for using subjunctive mood, and the adverb "fardă (tomorrow)" as a marker for using present tense, and therefore they apply present subjunctive (šerkat konand (to take part)). However, they often have problem in completing a sentence like "emrooz ba'dazzohr miaee baham be cinema ... (raftan (to go)),"

and, instead of present subjunctive (beravim (we go)), they usually use present indicative (miravim (we go)). This problem stems from the fact that moods and grammatical tenses of verb and usages of verb in different situations and contexts are presented gradually in textbooks and sources of Persian language teaching, in a way that the regularities of verb moods choice is ignored by teachers and language learners. Therefore, language learners face different kinds of compound sentences, in some of which indicative mood and in some others subjunctive mood is used, but the common point of these sentences is ignored by language learners, so they have to memorize various cases without finding a specific justification for them.

In the present study, subjunctive mood was taught to 30 foreign students (Arab speakers) of Shahed University. These participants were in two classes composed of 15 students (of medicine and engineering), and they were taking four-credit course of General Persian. Their language proficiency level was intermediate. At the beginning of the teaching, a pretest was given to the students. This test composed of two speaking and two writing passages with twenty blank spaces. With regard to the given infinitive, the participants were required to conjugate the verb and fill in the blanks. Ten verbs with indicative mood and ten others with subjunctive mood had to be inserted in the blanks.

The results of the pretest showed that language learners had guessed 89 percent of the indicative verbs correctly, but responses related to subjunctive mood revealed that the subjects of the study had problem in the comprehension and application of this mood and that just 23 percent of responses were correct. No significance differences were discerned between the results of the two classes.

After this stage, teaching subjunctive mood to the two classes started. A class was chosen as the experimental group (henceforth class no.1), and the other class as control group (henceforth class no.2). Using the concept of mental spaces and space-builder, the subjunctive mood in sentences with modal verb, in imperative sentences, and in probable conditional sentences were taught to the subjects during two sessions. In the following session, the use of subjunctive mood in sentences expressing a request or a suggestion was taught and then the use of subjunctive mood in compound sentences was illustrated in three sessions. In the same vein, above-mentioned sentences were taught to the subjects of the control group. For this group, however, educational content existing in different textbooks was chosen and, like educational sources, focus was more on the formal construction. All the sentences were presented to the language learners in the context of speech or written text. An example of the use of mental spaces in the sentences is given here:

1. lăzem ast ke xănom-e Părsă ham be injă mi-ăyad.

necessary is that Mrs Parsa too to here come (present indicative). (It is necessary that Mrs. Parsa come here.)

2. lăzem ast ke ăqă-ye Năderi ham be injă bi-ăyad.

(necessary is that Mr Năderi too to here come (present subjunctive). It is necessary that Mr. Naderi come here as well.)

3. lăzem bud ke ăqă-ye Nuri ham be injă mi-ămad. 

here.)

necessary was that Mr Nuri too to here come (past progressive (impossible)). (It was necessary that Mr. Nuri come

These three sentences are instances of subjective compound clauses in which bound clause plays the role of the subject of the main clause. Main clause "lăzem ast" (It is necessary) be considered as a space-builder which builds a new space. This space-builder can form three types of spaces:

* Indicative space

* Subjunctive space

* Counterfactual space

Indicative space represents a definite scenario in which the speaker is sure about occurrence of the verb and shows this certainty through indicative mood. Subjunctive mood shows a probable scenario and in this space the speaker believes that the verb would probably occur. In counterfactual space, the speaker represents failed scenario, and by applying impossiblele mood (grammatical tenses of past progressive and past perfect) shows that there is no possibility for the verb occurrence. These three spaces are recognizable in sentences 1-3 above.

In sentence (1) the verb "mi-ăyad" possesses indicative mood and shows that speaker is sure about the occurrence of Mrs. Parsa's coming.

In the sentence(2) the verb "bi-ăyad" has a subjunctive mood, is in present tense and shows that the speaker considers "Mr. Naderi's coming" as a probable occurrence.

Sentence (3) indicates impossibility of "Mr. Nuri's coming" and this failed scenario has been displayed by past continuous tense. This usage of past continuous is called impossible/counterfactual by the author. These points can be shown as the following:

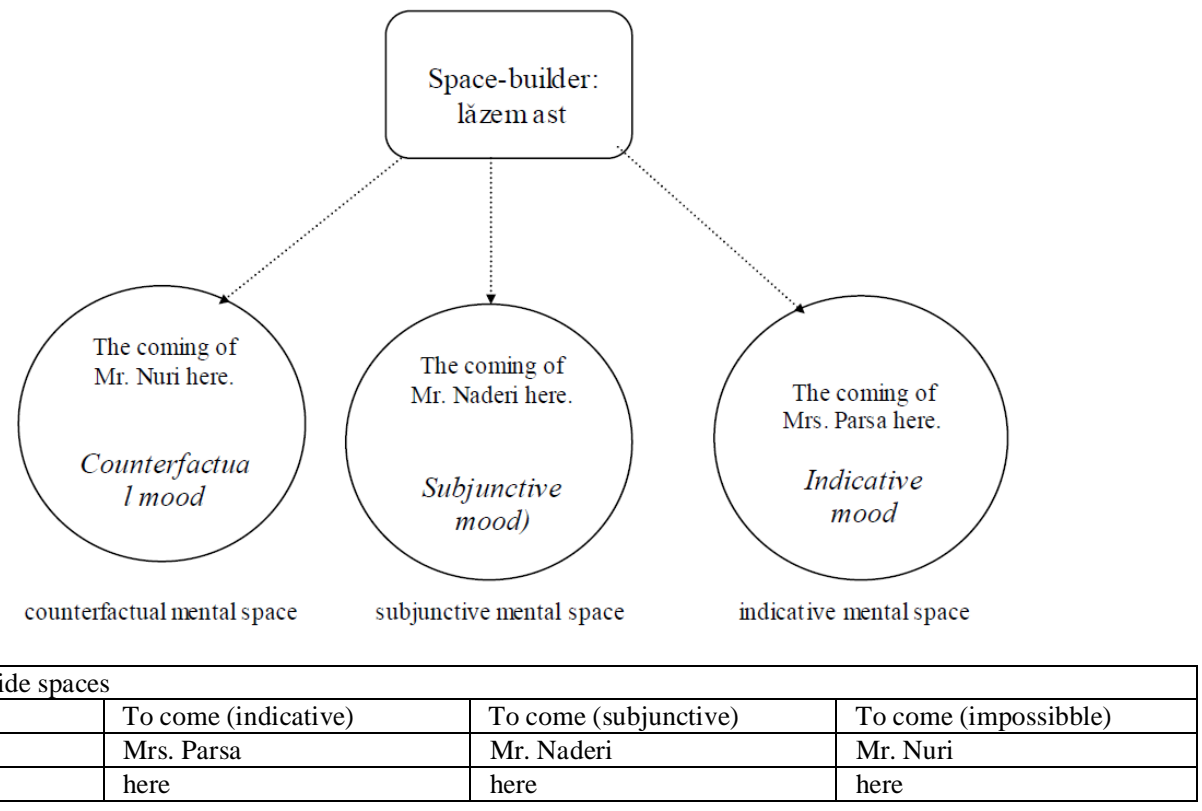

As it is shown, in these three spaces, mood is the indicator of space type, and a space-builder can form different spaces: indicative space in which the possibility of verb occurrence is inevitable, subjunctive space which shows that verb occurrence is probable, and impossible/counterfactual space which shows that verb occurrence is unlikely. In each of these spaces moods act as a meaningful grammatical category, and indicative space, subjunctive space and counterfactual space are represented by indicative, subjunctive and impossible moods respectively.

The sentences were given to the students within a speaking text. In this text which was about an official meeting, a clerk was talking with his boss about the presence of three of the participants in the meeting. By using these three sentences in the speaking context, the teacher explains that the first sentence shows the indicative mental space of the speaker; Because he is sure about Mrs. Parsa's coming, and in response to the question "why is Mrs. Parsa coming to the meeting?" he says: "it is necessary that she is coming". Speaker's assurance of verb occurrence is shown by indicative mood.

In the second sentence, the speaker believes that Mr. Naderi's coming is not definite; therefore, his mental space is the possible space in which he applies subjunctive mood. In the third sentence, the speaker is sure that Mr. Nuri won't take part in the meeting, but assumes his presence as necessary. Hence the speaker means to express impossibility of Mr. Nuri's coming. This sense is represented in impossible space and with past progressive tense.

Language learners learn the subjunctive mood usage through comparing these spaces, the elements inside them and identity connections between elements, and also through representing different moods in the spaces. 
In the control group, subjunctive mood in different sentences and texts was taught without presenting the concept of mental spaces. After teaching and giving different spoken and written practices, both groups received a post-test about tense and moods of the verbs in Persian language, and the results regarding subjunctive mood were examined.

The post-test consisted of a writing text with ten blank spaces, two dialogues, each having five blanks, ten multiplechoice questions and ten incomplete compound sentences. Language learners were supposed to fill in the blanks with appropriate mood and tense, and complete the compound sentences according to the given infinitive. In general, language learners were required to choose or conjugate 40 verbs. In ten cases of these verbs, modal verbs were used in the sentences. Since, modal verb helps the learner to use subjunctive mood appropriately, no significant differences were discerned between experimental and control group. The experimental group answered 94.6 percent of the sentences correctly and the control group 86.6 percent thereof. The experimental group had 142 correct answers, i.e. 94.6 percent, and the control group had 129 correct answers, i.e. 86 percent of 150 questions.

The frequency table (Table.1) and percentage table (Table.2) relating to sentences with modal verbs is presented below:

TABLE. 1

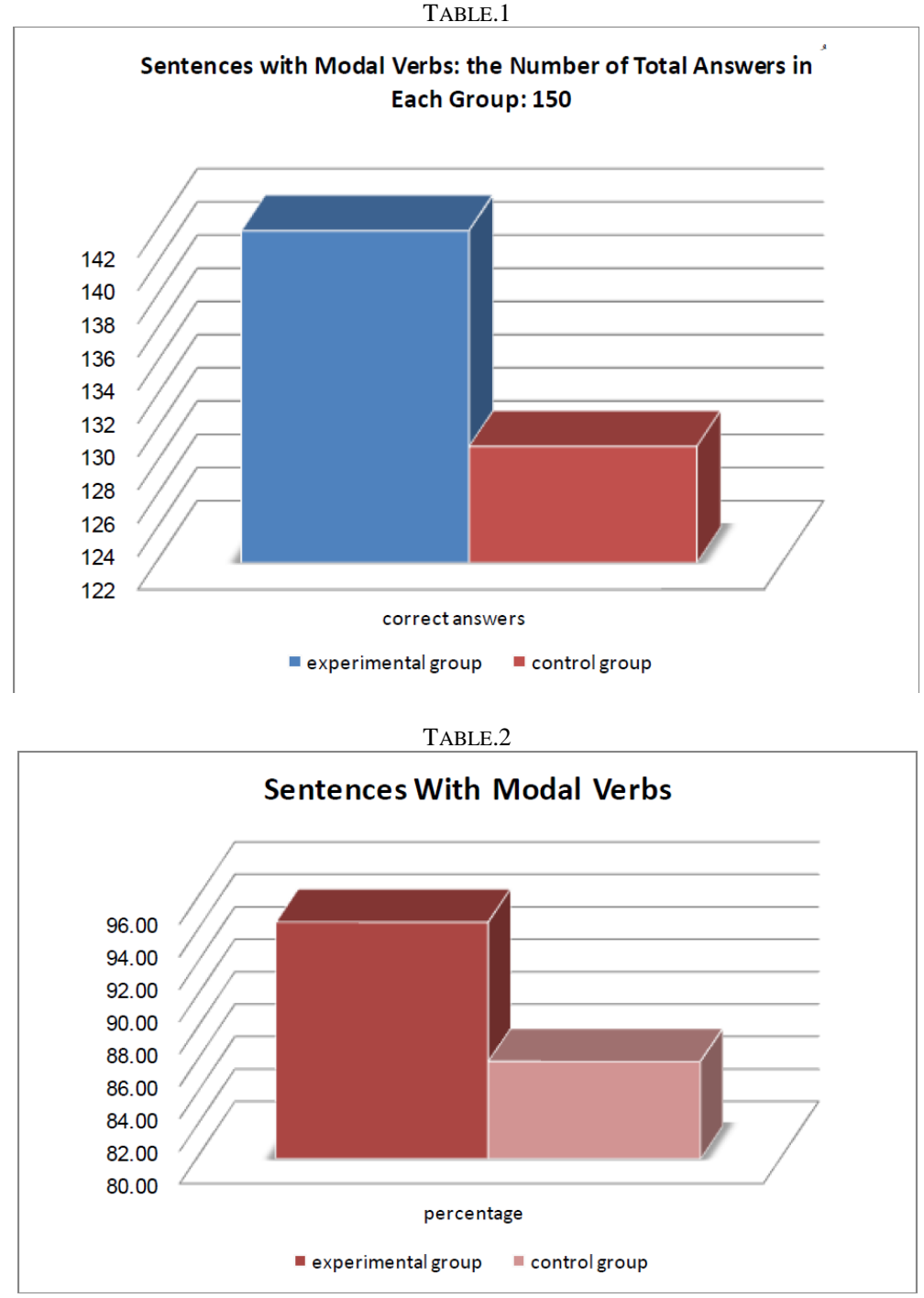

In the rest thirty cases, which included twenty-two various compound sentences and eight simple sentences indicating a suggestion or accepting a suggestion, wish, blessing, being in limbo and hesitation, subjects of the two groups answered rather differently. In general, experimental group answered correctly to 89.3 percent (402 correct answers out of 450 questions) and 70.4 percent (317 correct answers out of 450 questions) of the questions were answered correctly by the control group.

The frequency table (Table.3) and percentage table (Table.4) relating to sentences without modal verbs are presented below: 
TABLE. 3

\section{Sentences Without Modal Verbs: the Number of} Total Answers: 450

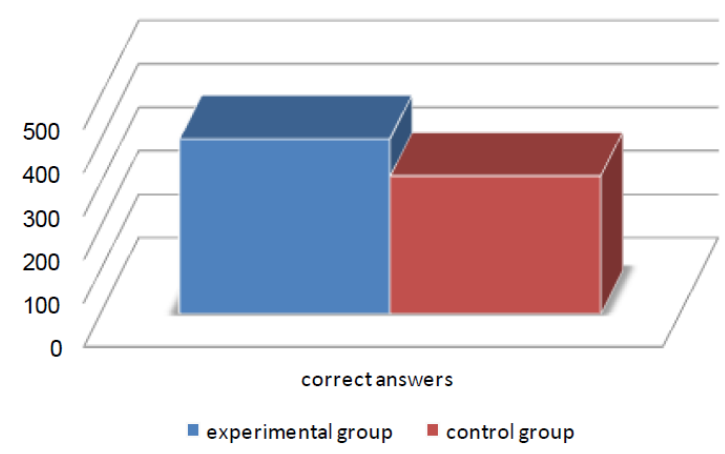

TABLE. 4

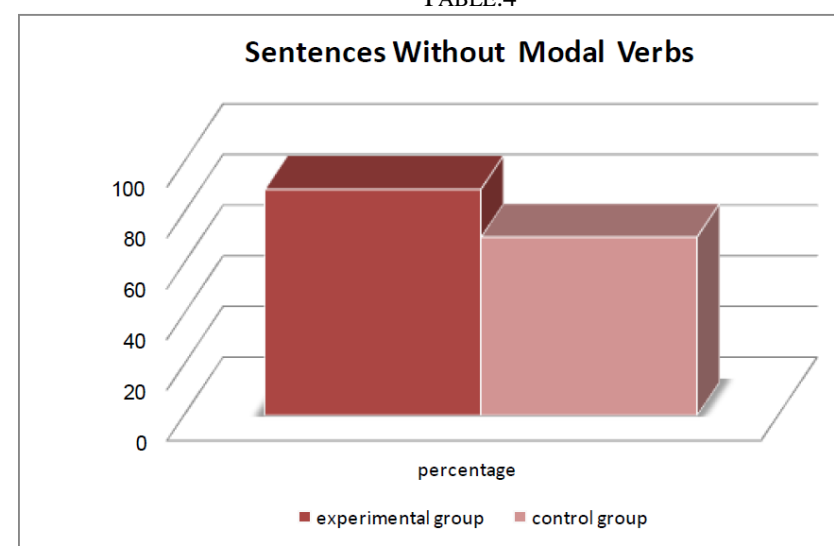

This difference between correct answers shows the positive effect of applying mental spaces theory in teaching subjunctive mood in Persian language. This is because of the fact that language learners familiar with mental spaces better understood the concept of mood in general (speaker's attitude to the soundness and truth of the speech), and mood usage in different sentences, and were better able to choose mood in various sentences. This result could be discerned in speaking skill of the students, because the experimental group outperformed control group in appropriate use of subjunctive mood and faced less problems in constructing compound sentences.

\section{CONCLUSION}

Learning subjunctive mood is usually problematic for non-native Persian learners. Even advanced learners have difficulty in applying subjunctive mood. The present article dealt with mood choice in compound and simple sentences according to mental spaces theory, and with teaching mood based on mental spaces. The participants of the study consisted of students of Shahed University of Tehran, who all had the same mother tongue (Arabic) and their language proficiency were considered as intermediate. After administration of the pretest and getting equal results, during six sessions, subjunctive mood was taught to the experimental group using mental spaces theory and to the control group without using this theory. Throughout these sessions language learners got familiar with subjunctive mood usage in various simple and compound sentences.

The results showed that those language learners who learned subjunctive mood by using the concept of mental spaces of the space-builders, and the probability of occurrence (as the central meaning of different moods), had a better performance in realizing and applying appropriate mood in various sentences. This demonstrates the positive effect of cognitive linguistics concepts and its theories on second language teaching. Moreover, Persian learners of the control group were better able to produce sentences the verbs of which expressed an impossible action (what the author calls impossible mood). Accordingly, by using this theory, the teacher can show the regularity of mood choice in various compound sentences in Persian language, and present a documentary justification for each choice, thus, learners can realize mood in Persian language with less probability of error.

\section{REFERENCES}

[1] Achard, M., Niemeier, S. (ed.) (2004). Cognitive Linguistics, Second Language Acquisition and Foreign Language Teaching. Berlin, New York: Walter de Gruyter Inc. 
[2] Ahmad Giwi, H. (2001). Historical Grammar of Verb, Vol. 2, 1st Ed., Tehran, Qatreh Pub.

[3] Chalker, S., (1995).Dictionary of English Grammar. Oxford: Oxford University Press.

[4] Cutrer, M. (1994). Time and Tense in Narratives and Everyday Language. Doctoral dissertation, University of California at San Diego

[5] Dirven, R., Verspoor, M. (2004). Cognitive Exploration of Language and Linguistics. Amsterdam, Philadelphia: John Benjamins.

[6] Ebrahimi, H., (2009). Advanced Writing (for Non-Iranian Language Learners), Tehran, Qatre Pub..

[7] Ellis, N. C. \& Robinson P., (2008 b). Handbook of Cognitive Linguistics and Second Language Acquisition, Routledge.

[8] Ellis, N. C. (2008 a). Usage-based and form-focused SLA: The implicit and explicit learning of constructions. In A. Tyler, Y. Kim, \& M. Takada (Eds.) Language in the context of use: Cognitive approaches to language and language learning (pp. 931205). Berlin: Mouton de Gruyter.

[9] Esfahani, M.H., (1308 A.H). Persian Elementary School, 1st Ed, Istanbul.

[10] Farshidvard, Kh. (1969). Today's Grammar, Tehran, Safi 'Ali Shah Press Institution.

[11] Farshidvard, Kh. (2003). today's Extensive Grammar, Tehran, Sokhan Pub.

[12] Fauconnier, G., (1985). Mental spaces, Cambridge, MA: MIT Press.

[13] Fauconnier, G., (1994). Mental Spaces. New York: Cambridge University Press.

[14] Fauconnier, G., \& E. Sweetser. (1996). Spaces, Worlds, and Grammar. Chicago: University of Chicago Press.

[15] Fauconnier, G. \& M. Turner. (2002). The Way We Think. New York: Basic Books.

[16] Fowler, H. W. (1926). A Dictionary of Modern English Usage. Oxford University Press.

[17] Gass, S. (1997). Input, interaction and the second language learner. Mahwah, NJ: Erlbaum.

[18] Gass, S, M, \& Selinker S., (2008). Second language acquisition: An Introductory Course (3rd Edition). New York: Routledge.

[19] Halliday, M.A.K., (1985).An Introduction to Functional Grammar. London: Arnold.

[20] Halliday, M.A.K., (1994). An Introduction to Functional Grammar (2nd edition). London: Arnold.

[21] Halliday, M.A.K. \& Matthissen, M, I, M.. (2004). An Introduction to Functional Grammar. London: Arnold.

[22] Hardie, R. G. (1990). English Grammar. London: Harper Collins.

[23] Homayoun Farrokh, A. (1985), Comprehensive Persian Grammar, with the help of Rokn al-din Homayoun Farrokh, 3rd Ed., Tehran, Elmi Pub..

[24] Khayampour, A. (1996). Persian Grammar, 10th Ed, Tehran, Tehran Book Store.

[25] Li, Jian. (1999). Modality and Meaning of Modal Auxiliaries. Journal of Foreign Languages. 1999 (4): pp19-23.

[26] Lyons, John, (1977). Semantics (Vol. 2). Cambridge: Cambridge University Press.

[27] Mortelmans, Tanja, (2007), Modality in cognitive linguistics in Guyckens, H., \& Dirk, G., The handbook of cognitive linguistics, Routledge.

[28] Natel Khanlari, P. (1987). Persian Grammar, 8th Ed., Tehran, Novin Pub.

[29] Oxford, R., L. (1990). Language Learning Strategy, What every teacher should know. Boston, MA: Heinle and Heinle.

[30] Palmer, F. R. (1986). Mood and Modality. Cambridge: Cambridge University Press.

[31] Pournamdarian, T. (2007) Persian for Foreign Learners, Tehran, Humanities and Cultural Studies Research Center.

[32] Putz M., Niemeier S., Dirven R. (ed.) (2001). Applied Cognitive Linguistics I,II: Theory and Language Acquisition. Berlin, New York: Mouton de Gruyter.

[33] Qarib, A. A. (1955). Persian Grammar, 3rd Series, 29th Ed., Tehran, Scientific Islamic Book Store.

[34] Quirk, R. et al. (1985). A comprehensive Grammar of the English Language. London: Longman.

[35] Sadeqi, A.A. \& Arzhang, Gh. (1982). Grammar of 4th Grade High School, FarhangvaAdab Pub.

[36] Saeed. J, R, (1997). Semantics, Oxford: Blackwell.

[37] Saffar Moqadam, A., (2003). General Persian 1, Basic Structures, Tehran, Persian Language and Literature Development Counsel.

[38] Saffar Moqadam, A., (2007). Persian Language, Tehran, Persian Grammar and Literature Development Counsel.

[39] Samareh, Y. (1993). Teaching Persian Language, Al-Hoda International Publication.

[40] Schmidt. R. (1994). Deconstructing consciousness in research of useful definitions for applied linguistics. AILA Review 11:1126.

[41] Shafaee, A. (1984). Scientific Foundations of Persian Grammar, Tehran, Novin Pub.

[42] Tomlin, R. \& V. Villa. (1994). Attention in Cognitive science and second Language Acquisition. Studies in Second Language Acquisition 16: 183-203.

[43] Vahidian, K., Omrani, Gh.,Omrani, T. (2002). Persian Grammar, 3rd Ed., Tehran, Samt.

[44] VanPatten, B. (1996). Input processing and grammar instruction in second language acquisition. New York: Ablex.

[45] Yasemi, R. et.al. (1994). the Grammar of Five Teachers, under Siros Shamisa's supervision, 1st Ed., Tehran, Ferdous Pub.

[46] Zarghamian, M. (2002). Fact-to-Learn Book of Persian Language, Tehran, ILI Pub.

[47] Zarghamian, M. (2003). Series of Teaching Persian, Basic to Advanced, Tehran, -Persian Language and Literature Development Counsel.

[48] Zarghamian, M. (2010). Persian language, General Series, Basic, Tehran, ILI Pub. 


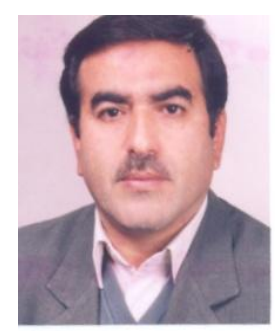

Ferdows Aghagolzadeh Silakhori was born in Babol, Iran, in 1956. He received the B.A. degree in English Language and Literature from Allameh Tabatabaee University, Tehran, Iran, 1984; and M.A. and Ph.D degrees in Linguistics from Tarbiat Modarres University, Tehran, Iran, in 1991 and 2002 respectively. Complementary researches of Ph.D. were done in Liverpool University of England.

$\mathrm{He}$ is an Associate Professor and a Faculty Member of Linguistics Department of Tarbiat Modarres University, Tehran, Iran. He has been the Chair of Language Laboratories since 1996, and in 2006, he was the Head of Linguistics Department of Tarbiat Modarres University. He has published more than 70 papers and books in the field of language and literature. His current research interests include discourse analysis and Pragmatics, applied linguistics, literature and linguistics, and dialectology.

Dr. Aghagol Zadeh is a member of Iran Linguistics Association, Iran English Language and Literature Association, Persian Language and Literature Association, and Iranian Literary Criticism Association.

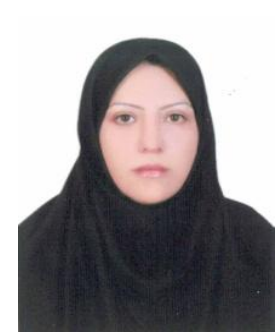

Zahra Abbasi was born in Tehran, Iran, in 1975. She received the B.A. degree in German Translation from Tehran University, Tehran, Iran, in 1997 and M.A. degree in Teaching Persian to Foreigners from Allameh Tabatabaee University, Tehran, Iran, in 2002. Abbasi is a Ph.D. Candidate in General Linguistics in Tarbiat Modarres University, Tehran, Iran.

She has been teaching Persian to foreigners in Iran Language Institute (ILI) since 2001. From 2003 to 2007, she taught Persian Language to Foreign staff and presenters of IRIB World Service (Channels of Al-Alam and Sahar, and Oversees Radios). Since 2009, she has been a Lecturer at Shahed University teaching Persian to foreign students. She has published more than 7 papers and 3 books in the field of Persian Teaching to nonteaching, and bilingualism

natives. Her current research interests include syntax, applied linguistics, second and foreign language

Mrs. Abbasi is currently the Manager of the Persian Language Department of Iran Language Institute (ILI), and also the Head of the Department of Non-English Languages of ILI. 